Research, part of a Special Feature on Navigating Trade-offs: Working for Conservation and Development Outcomes

\title{
When Donors Get Cold Feet: the Community Conservation Concession in Setulang (Kalimantan, Indonesia) that Never Happened
}

\author{
$\underline{\text { Sven Wunder }}^{1}$, Bruce Campbell $^{2,3}{ }^{\text {Peter GH Frost }}{ }^{1}$, $\underline{\text { Jeffrey A. Sayer }}^{4}, \underline{\text { Ramses Iwan }}^{1}$, and
} Lini Wollenberg ${ }^{5}$

\begin{abstract}
There is consensus that payments for biodiversity services are a promising conservation tool, yet the implementation of applied schemes has been lagging behind. This paper explores some reasons why potential biodiversity buyers may hesitate. It describes the case of an unsuccessful attempt to establish a community conservation concession in the village of Setulang (East Kalimantan, Indonesia) to safeguard a biologically valuable area from predatory logging. Potential biodiversity donors did not engage in this payments-for-environmental-services scheme mainly because of their limited time horizon and uneasiness about the conditionality principle. Other complicating factors included overlapping land claims, and the diagnosis of the externality at hand. We conclude that new investment modalities and attitudes are needed if potential biodiversity buyers are to exploit the advantages of this innovative tool. We also provide some tangible recommendations on factors to consider when designing a compensation scheme for conservation at the community level.
\end{abstract}

Key Words: conservation; Kalimantan; logging; payments for environmental services

\section{INTRODUCTION}

Concern is growing over the maintenance of environmental services, particularly those dependent on biodiversity and that were previously obtained for free. Changes in land use and land cover increasingly threaten the integrity of landscapes and reduce biodiversity (Hassan et al. 2005). Attempts to create synergy between conservation and development by, for example, implementing integrated conservation and development programs (ICDPs) have so far had limited success (Kramer et al. 1997, Brandon et al. 1998). A recent novel concept, direct payment for environmental services (PES), is attracting considerable interest as a potentially more efficient conservation tool (Ferraro and Kiss 2002) that also bridges trade-offs vis-à-vis poverty alleviation (Grieg-Gran et al. 2005). A PES can be defined as a voluntary, contingent transaction between at least one buyer and at least one provider of a well-defined environmental services - or a land use likely to produce that service (Wunder 2007). Strong theoretical arguments have been made that
PES should be more cost efficient than both ICDPs and "green premium" approaches (e.g., ecotourism), mainly because direct contractual conservation does not require costly investments in alternative production lines (Simpson and Sedjo 1996, Ferraro 2001, Kiss 2004, Ferraro and Simpson 2002, 2005).

Where have actual PES and PES-like schemes been applied? Table 1 provides some examples, drawn from long-standing initiatives, some of which extend back to 1985 . Most have been implemented in Latin America and in developed countries. The latter are mainly agri-environmental payment schemes in which the State is the buyer, often of multiple services. Some of these schemes are large, up to 14.5 million ha for the US Conservation Reserve Program, for example. Conversely, in developing countries, many schemes are small and self-organized, e.g., operating at the level of a single micro watershed (around 500 ha in Pimampiro, Ecuador). Payment is seldom made directly for service delivery, but rather for changed land-use practices that are presumed to provide the targeted 
service(s). As shown in Table 1, many stakeholders can be involved in PES deals, for instance, with a public agency or non-governmental organization (NGO) acting as the honest broker to mediate between service sellers and buyers.

Biodiversity conservation concessions are one of the tools within the PES approach. Because habitat loss is the main factor driving the extinction of tropical biodiversity, area-based incentive schemes such as conservation concessions or easements seem particularly well suited for conserving biodiversity (Hardner and Rice 2002, Niesten and Rice 2004), although some have criticized their possible negative social impacts (Karsenty 2004, Romero and Andrade 2004). With the incentive of being seen to lead the way, some agencies have recently funded PES scoping studies and other initiatives that could guide future developments, e. g., the Global Scoping Study on Compensation for Ecosystem Services, funded by Canada's International Development Research Centre (http:// www.worldagroforestrycentre.org/cres/) and Developing Markets for Watershed Protection Services and Improved Livelihoods, funded by the UK Department for International Development(http://w ww.iied.org/NR/forestry/projects/water.html).

In many cases, it is unclear just who will pay for biodiversity and the services it provides (see Hassan et al. (2005) for a description of such services, and Hooper et al. (2005) for a consensus on the links between biodiversity and ecosystem functioning). Most of these conservation services are desired for the long term, so PES has to be continuous, at least while the threats remain. Private donations channeled through conservation organizations currently seem the best bet. Conservation International (CI) and the Global Conservation Fund (GCF) have experimented with conservation concessions and conservation-incentive agreements for some years (Niesten and Rice 2004). The Nature Conservancy (TNC) and the World-Wide Fund for Nature (WWF) have explored this concept more recently. The Global Environmental Facility (GEF) has experimented with direct biodiversity payments in Costa Rica, Nicaragua, and Colombia (Pagiola et al. 2004). Both GEF and bilateral conservation donors often make enabling investments, but expect others eventually to sustain the payments. Deals with private companies that use biodiversity as a production input, for example, the bio-prospecting contracts between the Costa Rican National Biodiversity Institute, INBio, and various pharmaceutical companies, have so far produced negligible conservation rents. Development donors and NGOs are interested in the poverty alleviation potential of PES, but hesitate to go beyond pilot schemes. If so many in conservation and development think PES is a good idea, why not test this tool further by funding such schemes?

This paper describes an unsuccessful attempt to design a PES scheme and get it funded. It focuses on lessons learned about the difficulties of securing direct, area-based, contingent payments to conserve biodiversity, and our understanding of the reasons for this failure despite the good intentions on all sides. The idea involved paying the community of Setulang, situated in Malinau district in East Kalimantan (Indonesian Borneo), to keep their 5300-ha forest intact rather than sell the logging rights to a timber company. The area, close to Kayan Mentarang National Park, is one of a few remaining patches of pristine forest in the lowland-mountain transition zone. Between 2000 and 2003, the area was threatened by a wave of logging sweeping through the district, as well as by increasing pressures to convert forest to other land uses, both of which threatened the biodiversity values of the region. One of us (Sayer) first discussed the idea with the villagers of Setulang in 2000. It was received positively. For the Center for International Forestry Research (CIFOR), this initiative provided a chance to "learn by doing," a process that might help to produce a replicable model of conservation with local rewards. Therefore, we negotiated for more than 18 months with three donors: one international conservation organization and two corporate enterprise funds. Despite prolonged negotiations, we were unable to convince any of the three to support the idea. The obstacles we encountered are probably more general than this particular case.

The paper is organized as follows. The next section describes Setulang village, its history, land use, biodiversity context, and community conservation actions, and the influence of the logging industry. Following that, we describe in more detail the interactions between Setulang and various logging companies. We then explain the idea of the community conservation concession and how it was received by both the local community and the prospective donors. Finally, we discuss the outcomes and their consequences before concluding with some lessons learned. 
Table 1. Examples of PES-type experiences worldwide (RISEMP = Regional Integrated Silvopastoral Ecosystem Management Project; NGO = non-governmental organization; IO = international organization; n.a. = not available).

\begin{tabular}{|c|c|c|c|c|c|c|c|c|}
\hline Scheme & Location(s) & Service(s) & $\begin{array}{l}\text { Land uses } \\
\text { paid for }\end{array}$ & $\begin{array}{l}\text { Seller age- } \\
\text { ncy }\end{array}$ & $\begin{array}{l}\text { Scale of } \\
\text { transaction }\end{array}$ & $\begin{array}{l}\text { Spatial extent } \\
\text { (ha) }\end{array}$ & $\begin{array}{l}\text { Start } \\
\text { year }\end{array}$ & Source(s) \\
\hline RISEMP & $\begin{array}{l}\text { Colombia } \\
\text { Costa Rica } \\
\text { Nicaragua }\end{array}$ & $\begin{array}{l}\text { Biodiversity, } \\
\text { carbon }\end{array}$ & $\begin{array}{l}\text { Restoration } \\
\text { (silvopasture) }\end{array}$ & $\begin{array}{l}\text { NGOs, IO, } \\
\text { states }\end{array}$ & International & 3500 & 2002 & $\begin{array}{l}\text { Pagiola et al. (2004, } \\
\text { 2007) }\end{array}$ \\
\hline Pimampiro & Ecuador & Watershed & $\begin{array}{l}\text { Conservation/ } \\
\text { minor restor- } \\
\text { ation }\end{array}$ & $\begin{array}{l}\text { Municipal } \\
\text { government }\end{array}$ & Local & 496 & 2000 & $\begin{array}{l}\text { Echavarría et al. } \\
\text { (2004), Wunder and } \\
\text { Albán (2008) }\end{array}$ \\
\hline $\begin{array}{l}\text { Working for } \\
\text { Water Prog- } \\
\text { ramme }\end{array}$ & South Africa & $\begin{array}{l}\text { Watersheds, } \\
\text { biodiversity }\end{array}$ & Restoration & $\begin{array}{l}\text { Central St- } \\
\text { ate }\end{array}$ & National & n.a. & 1995 & Turpie et al. (2008) \\
\hline $\begin{array}{l}\text { Conservation } \\
\text { Reserve Pr- } \\
\text { ogram }\end{array}$ & USA & $\begin{array}{l}\text { Watersheds, } \\
\text { biodiversity, } \\
\text { soil protection }\end{array}$ & $\begin{array}{l}\text { Restoration } \\
\text { (agricultural } \\
\text { practices; land } \\
\text { retirement) }\end{array}$ & $\begin{array}{l}\text { Central St- } \\
\text { ate }\end{array}$ & National & 14500000 & 1985 & $\begin{array}{l}\text { Claassen et al. } \\
(2008)\end{array}$ \\
\hline PROFAFOR & Ecuador & Carbon & $\begin{array}{l}\text { Restoration } \\
\text { (plantation) }\end{array}$ & $\begin{array}{l}\text { Private co- } \\
\text { mpany }\end{array}$ & $\begin{array}{l}\text { Regional -- } \\
\text { mostly Andes }\end{array}$ & 22300 & 1993 & $\begin{array}{l}\text { Albán and Argüello } \\
\text { (2004), Wunder and } \\
\text { Albán (2008) }\end{array}$ \\
\hline PSA & Costa Rica & $\begin{array}{l}\text { Carbon, wa- } \\
\text { tersheds, bi- } \\
\text { odiversity, } \\
\text { landscapes }\end{array}$ & $\begin{array}{l}\text { Conservation/ } \\
\text { minor restor- } \\
\text { ation }\end{array}$ & $\begin{array}{l}\text { Public sec- } \\
\text { tor+ }\end{array}$ & National & 270000 & 1996 & Pagiola (2008) \\
\hline Vittel & France & Watershed & $\begin{array}{l}\text { Conservation/ } \\
\text { restoration } \\
\text { (agricultural } \\
\text { practices) }\end{array}$ & $\begin{array}{l}\text { Private co- } \\
\text { mpany }\end{array}$ & Local & 5100 & 1993 & Perrot-Maître (2006) \\
\hline
\end{tabular}

\section{CONTEXT}

\section{History and Land Use}

Setulang Village $\left(3^{\circ} 27^{\prime} 12^{\prime \prime} \mathrm{N}, 116^{\circ} 29^{\prime} 56^{\prime \prime} \mathrm{E}\right)$ is located in the Malinau River watershed at the junction of the Setulang and Malinau rivers, $29 \mathrm{~km}$ upstream from Malinau, the district capital. This watershed is the most densely populated and developed rural area in the district, supporting about 6673 people distributed among 21 settlements (Voting Census data April 2003), although overall rural population density is low (average 1.3 person/ $\mathrm{km}^{2}$, Wollenberg et al. (2007)). In 2005, 945 people (226 households) lived in the village in five community clusters (Gunarso et al. 2006).

The village lands cover 11800 ha, more or less equally partitioned between an alluvial plain flanking the Malinau River, and containing the settlement and agricultural lands, and a forested upland area, at 150-500 m elevation, steeply dissected by numerous small streams that flow into the Setulang River (Fig. 1). The economy is based on a combination of subsistence agriculture, the sale of surplus crops, particularly rice, in Malinau town, and the extraction of forest products such as game, 
fibers, and poles. Off-farm income comes mainly from younger people working for timber companies in Malaysia and overseas, money that is used for buying large capital items such as electricity generators or outboard motors, or for building houses. By local standards, Setulang is not a poor village, because of-among other things-its considerable agricultural production (Iwan 2003).

The people in Setulang belong to the Kenyah Oma' Long (Dayak) ethnic group, in contrast to surrounding communities, which comprise a more heterogeneous mix of Punan, Putuk, Abai, and Kenyah Uma' Lasan ethnic groups. The villagers of Setulang are relatively recent immigrants to the area, having moved in 1968 from their previous settlement at Long Sa'an, a remote village $125 \mathrm{~km}$ away on the upper reaches of the Pujungan River, to gain better access to markets and social services. The move was authorized by the Malinau River Customary Chief and the Subdistrict Administrator in Malinau. It was confirmed by the Bulungan Regent in 1974, in a written decree that broadly described Setulang's upstream and downstream limits with the villages of Setarap and Sentaban respectively, but not precisely the interior boundaries (Iwan 2003). Whereas those in Setulang claim that they moved into an empty area, more likely it was being used extensively by neighboring villages (de Beer 2003).

\section{Land Use and Land Cover}

The villagers of Setulang practice a mix of shifting cultivation, agroforestry, and semi-permanent gardening, supplemented by fishing, hunting, and gathering. About $42 \%$ of the village lands are cultivated or lying fallow (mainly under bush and scrub), $44 \%$ is primary forest, $13 \%$ degraded forest, and $1 \%$ rivers and fringing vegetation (derived from a digital land-cover map prepared by CIFOR's Geographic Information Systems Unit using Landsat 7 data). Most of the lowland has been modified through transformation to agricultural land and timber extraction for local building materials, but the upland, which forms the catchment of the Setulang River, remains relatively intact. In mid 2000, the community set aside about 5300 ha of this area as a "Tane' Olen" (protected forest) to be used for subsistence hunting and to secure clean water (Iwan 2003). It is managed by the Tane' Olen Management Committee. Shifting cultivation in this area is prohibited, and effective internal rules only allow benign extractive uses. Active protection measures are taken against intruders. Except for a couple of episodes (described below), the forest has never been logged, and so appears largely undisturbed (de Beer 2003, Iwan 2003, Sidiyasa et al. 2006). In addition to the Tane' Olen forest, a smaller area on the other side of the Malinau River, also claimed by Setulang, contains important habitat for the Bornean gibbon (Hylobates mulleri). As this area is steep and rocky, the villagers had already set it aside for subsistence hunting and the extraction of non-timber forest products. The idea of actively conserving this area, other than for low-intensity use, arose during discussions with a World Conservation Union consultant (de Beer 2003) and was subsequently finalized when the community drew up its land-use plan with help from CIFOR (Iwan 2006, Limberg et al. 2007).

\section{Biodiversity and Conservation}

The natural vegetation of the area is classified as lowland mixed dipterocarp forest, dominated by trees in the families Dipterocarpaceae (21 species in five genera: Shorea, Dipterocarpus, Dryobalanops, Parashorea, and Vatica), Myristicaceae (13 species in four genera, including Knema (5 species), Myristica (4), and Horsfieldia (3)), Lauraceae (12 species in seven genera, including the important timber species Eusideroxylon zwageri). A forest inventory along four $20 \mathrm{~m}$ wide parallel transects, spanning $24.9 \mathrm{~km}$ overall within the Tane' Olen, was carried out in 2004-2005 with the assistance of knowledgeable villagers. The mean density and volume of trees $>20 \mathrm{~cm}$ diameter at breast height (DBH) was 201 individuals/ha and $421 \mathrm{~m}^{3} / \mathrm{ha}$, respectively (Sidiyasa et al. 2006). More detailed sampling of trees $>10 \mathrm{~cm} \mathrm{DBH}$ in 67 0.01-ha quadrats along the transects produced 157 species belonging to 90 genera in 46 families, higher numbers than those recorded during other forest inventories carried out in Kalimantan, except for Apo Kayan, East Kalimantan, where 175 species were recorded in quadrats totaling 0.8 ha. When adults, saplings, and seedlings are considered together, a total of 218 tree species belonging to 120 genera in 53 families were recorded in the 0.67 ha sampled (Sidiyasa et al. 2006).

We currently do not have detailed measures of the richness of other components of biodiversity in this particular forest. Some species of global and 
Fig. 1. Location of Setulang Village in Malinau District, East Kalimantan, Indonesia, showing generalized vegetation cover and land use, as well as the two protected community forest areas (one proposed) referred to in the text.

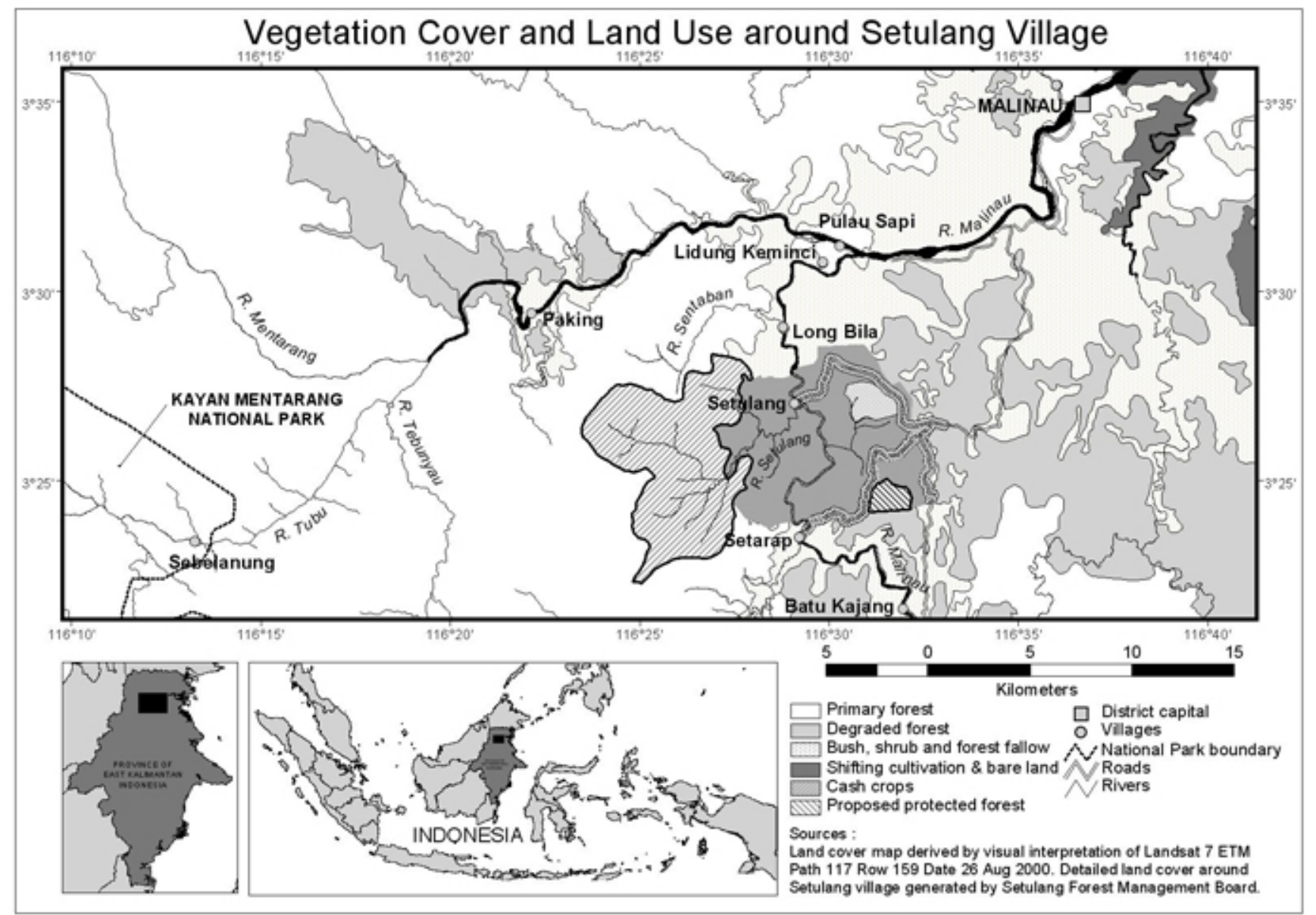

national conservation concern have been noted, including Malayan sun bear (Ursus malayanus), the tree ferns Cyathea borneensis and C. glabra, and the palm Caryota no (de Beer 2003, Sidiyasa et al. 2006). More broadly, the forest is situated on the fringe of the proposed Heart of Borneo transboundary conservation area, a $220000 \mathrm{~km}^{2}$ region of rainforest spanning the highlands of Brunei, Indonesia, and Malaysia. After the Amazon and Congo Basin forests, this is the world's third largest remaining tropical forest, and a globally important center of biodiversity, some of it still undescribed. During detailed biological surveys of the Malinau Research Forest, just south of Setulang, more than 2000 plant species were recorded from among 15430 plants surveyed. Of these, more than 900 were tree species within 280 genera and 80 families (Sheil 2002). A single 1-ha plot produced 207 tree species with stems $>10 \mathrm{~cm} \mathrm{DBH}$, one of the richest plots yet surveyed in Indonesia (D. Sheil, personal e-communication, 30 January 2008). These surveys also documented 239 species of birds (about $86 \%$ of those expected for the area), 37 species of mammals $(56 \%$ of the potential maximum), 40 species of amphibians (with four more reliably reported by local people), 55 species of reptiles, and 42 species of fish (Meijaard et al. 2005). The biodiversity of this region is exceptional. 


\section{Forest Clearance}

The lowland dipterocarp forests of Kalimantan are not only the most diverse of Indonesia's forests, but also arguably the most threatened. Lowland forest cover declined by $58 \%$ from an estimated 11.1 million ha in 1985 to 4.7 million ha in 1997, an annual rate of loss of $7 \%$, well above the $2.1 \%$ annual loss of forest cover generally in Kalimantan (Holmes 2002). Forest cover has continued to decline at about $2 \%$ per year, although no breakdown by forest type is available (Fuller et al. 2004). The main causes of forest loss have been large-scale logging, alone or in conjunction with land clearance for purposes of establishing industrial plantations (mainly for timber and palm oil); small-scale clearance for subsistence agriculture, small plantations, or the establishment of new settlements under Indonesia's former transmigration scheme. Forest fires, often lit deliberately when clearing large areas of land for industrial plantations, compound the problem (Holmes 2002, Forest Watch Indonesia/Global Forest Watch 2002).

\section{Logging}

Access to, use of, and responsibility for Indonesia's considerable forest resources has long been a source of tension between central government, provincial and district administrations, and local people. The balance of power has shifted with changes in governments and their policies, complicated by ambiguities in land designation, ownership, and rights, along with overlapping jurisdictions, selfserving authority, nepotism, and widespread unlawful activity at various levels (Brown 1999, Barr et al. 2001, Casson and Obidzinski 2007). Up to the late 1960s, local communities, district authorities, and regional administrations could undertake small-scale non-mechanized logging or issue permits for limited logging concessions, a system designed to secure the political allegiance and cooperation of local politicians for those in power (Obidzinski 2005). Most rural communities benefited only marginally through occasional employment. Difficulties of access usually limited the amount of timber extracted.

From 1970 onward, the government centralized control and allocated concessions, "Hak Pengusahaan Hutan," to large conglomerates with close ties to the family of the then-President, General Suharto, and to the military. The forests of Setulang fell within the concession area of PT Inhutani I, one of five state industrial forestry companies. All logging had to be mechanized, which excluded small-scale nonmechanized operators. Permit holders were required to practice selective logging, rotational harvesting, and enrichment planting on logged areas (Barr et al. 2001). Customary rights were eroded. People living in and around the concession areas received few benefits other than through occasional employment. Some allowed cutting to take place on community forest land, or engaged in illegal felling and sale of trees to timber companies (Obidzinski 2005). By all accounts, illegal logging was widespread, with timber processing capacity exceeding sustainable supply. Shortfalls were overcome by concessionaires harvesting more than their allowable annual cut, logging on short-rotation cycles or outside approved areas, and buying illegally harvested logs (Barr 2001, Smith et al. 2007).

Following the fall of Suharto in 1998 and the decentralization of many instruments of government, district authorities were authorized to issue smallscale logging permits, "Izin Pemungutan Pemanfaatan Kayu" (IPPK), for areas designated as either community or privately owned forest. These permits could be granted to individual landowners, cooperatives, farmers' and community conservation groups, or companies of various kinds (Barr et al. 2001). They allowed the holder to harvest timber and convert forest land to agriculture. Although legally the forests remained state land, revisions to the forestry law and a decree by the Ministry of Agriculture formally recognized "adat," the system of collective cultural beliefs, rights, and responsibilities held by different indigenous groups and administered by self-governing customary courts, laws, practices, and dispute-resolution processes (Alcorn 2000, Li 2001). This recognition enabled communities to lay legal claim to their forest resources and appropriate more of the timber rent.

Most IPPK concessions were harvested mechanically. Local timber brokers negotiated the transfer of rights to harvest timber from a community to a logging company or contractor in exchange either for cash or an in-kind settlement, or both, before securing the necessary IPPK from local government. Many logging companies with IPPK defaulted fully or partially on the promised fees, leaving communities with degraded forests. Cash 
transfers varied greatly depending on forest size, timber quality and access, and a community's negotiating skills, level of internal organization, strength of relationship with district government, and the credibility of threats to blockade logging operations in the event of non-payment (Engel and Palmer 2006, Palmer 2007, Wollenberg et al. 2006). Because the loggers were no longer backed by the military or by central government, forceful local communities were able to act against companies (see below). Increasing problems with IPPK caused the central government in 2000 to revoke the right of district authorities to issue IPPK. Following a further decree in 2002, logging under IPPK stopped in 2003 (Barr et al. 2006).

\section{INTERACTIONS BETWEEN SETULANG AND LOGGING COMPANIES}

The villagers of Setulang were affected by developments in the forestry industry in various ways. In 1974, two logging companies operating out of the neighboring villages of Sentaban and Setarap damaged some of the forests claimed by Setulang, causing the rivers to become turbid and threatening drinking water supplies. In 1995, a timber broker approached the community about logging the upper Setulang watershed, but was rejected. Between 2000 and 2002, at the peak of logging under IPPK, the community was approached by timber brokers on eight occasions to log the Tane' Olen forest. Despite the increasing value of these offers, the largest of which was priced at $\$ 300000$, a majority in the community chose to decline them, although minority voices started to perceive potential advantages in the offers (Iwan 2003).

In September 2002, villagers hunting in the upper Setulang watershed found that 33 meranti trees (Shorea sp.) had been logged and removed. They approached the camp of the company, CV Gading Indah, operating out of the neighboring village of Setarap, and confiscated their heavy machinery, bringing logging to a standstill. The village demanded compensation from the company of 5 billion rupiah (US\$555 000 at the prevailing exchange rate). Tough negotiations over the following month, mediated by the district government, resulted in the company agreeing to pay Rp.400 million (over US\$44 000) in compensation. Rp.200 million was paid in October 2002 (Iwan 2003). A further Rp.100 million was paid in early 2006; the balance is still outstanding. In December 2002, in a similar episode, PT Lestari Timur Indonusa started logging the Tane' Olen forest. Upon discovery, villagers impounded heavy machinery, removed the keys, and referred the matter to the sub-district administration (Iwan 2004). Various confrontations followed, but in the end, no compensation was paid (G. Limberg and R. Iwan, personal e-communication, 20 September 2007). Finally, the community successfully confronted the state logging company, PT Inhutani II, who had ordered villagers off their lands across the Malinau R on the grounds that these were part of Tanjung Lapang village, for whom PT Inhutani II was going to clear the land for agriculture.

By these actions, the community of Setulang showed its willingness to protect its forest and use force to halt logging. It also received substantial monetary compensation for one illegal intrusion. External pro-conservation interests acknowledged and supported these efforts. Because its main motive had been to conserve clean river water, Setulang was selected as one of three villages to represent Indonesia at a World Water Day ceremony in Kyoto, Japan in March 2003. Through CIFOR, Setulang was also nominated for, and in June 2003 received, the Kalpataru Award from the Indonesian Ministry of Environment for an outstanding effort to protect their local environment (Iwan 2003).

\section{THE COMMUNITY CONSERVATION CONCESSION IDEA}

In choosing to protect its forests and act forcefully and consistently against illegal loggers, Setulang acquired a reputation for exercising strong collective control over its natural resources (see Iwan 2003, 2006, and Anau et al. 2005 for details). Why then offer the villagers a community conservation concession (CCC), under which they would be paid for conservation, contingent upon their performance?

There were two main reasons for the idea. First, with the ever-mounting offers from logging companies, we perceived the danger that internal collective conservation preferences could erode; some community members had already argued that the offers should perhaps be considered. Second, pressures from external pro-logging interests were creating additional direct community protection costs (e.g., monitoring). In other words, both push 
and pull factors could mean that a tipping point might be reached in the future where conservation attitudes could be jeopardized. Payments under a CCC could counteract this.

Nevertheless, the CCC scheme was challenged by the partly overlapping land claims of neighboring communities, and by the economic interests of influential external pro-logging actors -in particular local government and logging companies-who would stand to lose if a CCC was implemented. Technical considerations include the extent of additionality, the potential for leakage, the permanence of the solution, and what constitutes an appropriate level of compensation (see below).

\section{Local Reactions}

We discussed the basic idea of a CCC with villagers at four meetings, and it was received positively. They suggested using the prospective payments for such things as financing the costs of forest protection, strengthening land tenure through land demarcation, and improving village infrastructure. Views differed on whether money should be disbursed directly to households. Most villagers saw an advantage in annual installments, rather than the one-off payments being offered by logging companies. They reasoned that, in other villages, the sudden appearance of relatively large amounts of cash had generated spending sprees with little long-term improvement in the quality of life. They thought it better to absorb smaller amounts of money received on a regular, predictable basis. This preference for smaller periodic disbursements over a larger early one-off payment suggests that people in Setulang have long planning horizons and are implicitly and unusually adopting a "negative discount rate": a sum of money paid upfront is valued less than the same quantity distributed periodically in smaller amounts in the future.

The community disliked the term "concession" in the CCC concept, associating it with external control (e.g., by logging companies). It clearly wished to retain control over land use. Moreover, the district government had said that, because logging concessions pay taxes, conservation concessions should do the same. The term "sponsorship" was thus preferred, the argument being that just as a football team could play with or without sponsorship, but would do better if sponsored, so too the community, in conserving its forest, would be more successful if supported externally (de Beer 2003). This retained the element of contingency, as the sponsor could withdraw if the contract was violated or the desired outcome was not achieved.

\section{Conservation Opportunity Costs and Concession Payments}

How much should those interested in conservation be prepared to pay to reward Setulang for conserving the forest? The timber stocks and biodiversity values of the Setulang forest had not yet been surveyed. The one-off payments offered by timber brokers to Setulang provide one measure of the opportunity costs of conservation, the benefit that the community would forego by deciding to conserve the forest. The highest offer was about US\$300 000 (Iwan 2003), corresponding to US $\$ 56.60 /$ ha or US $\$ 1442$ per household. It is possible that this amount was deliberately overstated to secure the permit, but with no intention of paying the full amount. Nevertheless, in the first CCC proposal prepared, based on preliminary consultations with Setulang, we sought an annual payment of US\$30 000/year, at least for an initial period of 5 years, which might be competitive with the timber broker's high one-off offer.

Later negotiations revealed that people would accept lower amounts, down to as little as US\$2000 per year (Setulang village meeting, April 2003). The motives for this seemed obvious: the community would stand to lose significant domestic benefitsclean water, game, building material, etc.-if the forest was logged. The value of these benefits needs to be subtracted before arriving at the net opportunity cost of conservation. Whereas some of these benefits (e.g., wood extraction) can be valued in economic terms, others such as clean water are more difficult. Some, e.g., cultural values, are basically impossible to express in monetary terms. It is questionable whether an explicit economic valuation exercise would add much insight in this case.

\section{Three Community Conservation Concession Proposals}

Between July 2002 and December 2003, the Center for International Forestry Research (CIFOR) prepared three proposals: two for corporate donors 
and one for an international conservation organization. Informal contacts with a foreign oil company operating in Indonesia suggested possible interest in funding conservation and communitydevelopment activities. The company's independently operated development fund had already financed conservation activities elsewhere, including the nearby Kayan Mentarang National Park. The proposal, for US\$205 000 over 5 years, was the largest of the three we prepared. Three-quarters of this-US $\$ 30000$ committed annually for 5 yearswas budgeted for community payments proper, based on assumed local opportunity costs. US $\$ 45$ 000 was set aside to facilitate cross-site visits by other communities and the production of a video, aimed at scaling-up the initiative if successful. The remaining US $\$ 10000$ was to fund an Indonesian student. CIFOR offered considerable counterpart resources, for example by helping to negotiate the agreement, monitor compliance, and document and analyze the process. The initiative eventually stalled for reasons similar to those encountered in negotiating the next proposal.

A large international bank's corporate fund for financing community-based conservation was contacted in early 2003. The fund's mandate was "to finance projects that help local communities become self-sufficient in terms of conservationbased economic development" (I. Fiszel-Bieler, personal e-communication, 21 July 2003). We requested US\$50 000, a much smaller grant than from the oil company, because of the donor's lower financing ceiling, shorter time horizon (maximum 3 years), and our recognition that Setulang would accept less for a pilot scheme. CIFOR was to provide counterpart commitments similar to those in the oil company proposal. Protracted negotiations took place in the first half of 2003. From the outset, the donor was concerned about the sustainability of the CCC, yet the time horizon was insufficient for a long-lasting CCC scheme. Our proposal, submitted in July 2003 , focused on creating a US $\$ 36000$ trust fund, with an estimated yearly $5 \%$ financial return (US\$1800). We hoped to supplement this with funds from other donors to produce a more competitive annual return. In contrast, the donor wanted the fund to yield a financial return for distribution to the community and provide rotating loans for productive activities within it. In a revised plan, we made the loans contingent on the community not selling their timber rights. An Indonesian NGO specialized in revolving funds would oversee implementation. It soon became clear that the donor would not support a scheme that placed a cap on local land use, or that tied support directly to compliance with this cap, as this appeared to be buying the land, something for which the fund had no mandate. Instead, the donor suggested a more conventional 3-year project, with activities centered on creating employment and generating additional income, aimed at distracting attention from the cashfor-logging option. Adopting this proposal would mean severing the link between performance and payment ("contingency"), a key concept of both PES and the CCC. It left little room for further negotiations.

An international conservation NGO, active in the field of conservation but with an increasingly people-oriented focus, was contacted in late 2002. It looked the most promising of the three options as the specific budget line to which we applied was described as involving long-term acquisition of land-use and ownership rights through purchase or lease. Two versions of the same proposal were submitted in 2003, the first for US\$38 000 and a revised one some months later for US\$41 160. In both cases around $75 \%$ of the total budget would be transferred in cash to an existing village community development fund, the balance being used for specific activities and training related to forest protection. Much time was spent clarifying issues and discussing critical points. As this was a new type of initiative, the donor investigated the options in detail, including hiring a consultant to visit both CIFOR and Setulang. Following the consultant's report (de Beer 2003), the donor decided not to finance the project under the specified budget line but encouraged resubmission if the focus shifted to "inter- and intra[-]village consultation, development of tourism facilities, establishing a credit union, improving school curriculum and implementation of forest (co)management activities" (M. Hoogeslag, personal e-communication, 15 December 2003). In effect, the donor wanted to pursue a more traditional Integrated Conservation and Development Project (ICDP). One reason was the perceived danger of the CCC intensifying conflict with neighboring villages over the unclear boundaries. A second was a dislike of the concept of "quid pro quo" payments: the consultancy report had identified "the risk of a too direct link between conservation and money given" (de Beer 2003). This sudden turnaround led CIFOR to abandon the proposal, because the innovative part of the project would be lost. A much smaller Rp 60 million (US\$6300) grant was eventually disbursed and split 
equally among the villages of Setulang, Sentaban, and Setarap to facilitate community-based forest management activities. Setulang used its funds to survey and demarcate the Tane' Olen forest (Sidiyasa et al. 2006), undertake training on ecotourism development and mushroom cultivation, improve communication with neighboring villages, and agree on rules and sanctions governing the protected forest (Gunarso et al. 2006).

\section{Rights, Rules, and Rewards}

Land tenure and resource access are critical factors affecting the feasibility of a CCC. Both depend on relationships with the State and neighboring communities. Setulang denies any uncertainty over its borders (Setulang village meeting, February 2003), but neighbors on three sides challenged the rights of Setulang, a village of recent immigrants, to claim all the forest area (de Beer 2003). Village land rights are well-defined in the core area, but are ambiguous along the margins, other than with Setarap, the southern neighbor, with which Setulang has established friendly relations and a clearly defined border. During Setulang's disputes with loggers, the contractors concerned operated out of neighboring village territories, claiming they were blameless because the village borders were unclear. Whether justified or not, this reflected various unresolved border conflicts. Fuzzy boundaries are accepted as long as there is little at stake, but once the potential high economic value of the resources therein is recognized and opportunities arise to harness it, land claims and conflicts intensify, the ambiguities of traditional rights are exposed, and there is a drive to establish property rights. To resolve these conflicts, steps were taken to establish dialogue among the villages concerned, out of which came broad agreement on the need to protect the remaining forest in each village territory. Nevertheless, agreeing on mutually acceptable boundaries remained the priority (Gunarso et al. 2006).

The legal status of Setulang's protected forest is also ambiguous. The District Forestry and Plantation Office claims that the contested forest was declared a protected forest in 1971 under the provincial landuse plan for East Kalimantan, although the villagers had no knowledge of this (Iwan 2004). If true, then Setulang would lose its leverage over the land and its right to compensation, because the government would then be in charge of protecting the forest.
Ironically, had this been the case previously, the area de facto would have been logged, but by exploiting all the uncertainties and ambiguities, Setulang effectively marginalized the 1971 declaration.

Setulang had held preliminary discussions with the Ministry of Forestry about declaring the upper Setulang catchment a Forest for Special Purposes ("Kawasan Dengan Tujuan Istimewa," KDTI), a process requiring a forest inventory and resolution of any border conflicts (P. Gunarso, personal ecommunication, 22 July 2003). At present, such a decree, issued by central government without the district government's consent, would be little more than a paper declaration. It would reduce the village's legal ownership and management flexibility, even more than if it was a protected forest. This could jeopardize the CCC proposal, which hinges on the assumption that the village can make proper, legal, land-use choices. If the forest was declared a KDTI, it would be meaningless to pay the community a contingency fee for merely respecting the law. With these drawbacks, Setulang has so far not pursued this option further.

In addition to the claims made by neighboring villages, other parties have interests in the outcome and could influence whether the Setulang forest should be logged or conserved. These include the central government in Jakarta, whose position is equivocal, recognizing both the long-term benefits of conservation and the more immediate contribution of logging to Indonesia's economy. Nevertheless, central government probably has limited influence on local land-use decisions, and so would not need compensation. In contrast, the district government is more influential although also subject to opposing forces. There are considerable public relations benefits in being seen to support the $\mathrm{CCC}$, an institutional novelty in Indonesia, thereby boosting the green image of Malinau District. Against this, the district government stands to lose logging revenues. On balance, district officials are probably largely opposed to the CCC. Without their approval, the scheme might be unsustainable. Whether and how the district government should be rewarded would have to be negotiated. Finally, logging companies and their intermediaries capture most of the timber rents and so stand to lose most from the CCC. They were obviously keen to log the area, and might lobby strongly against a CCC, but as they have no legitimate area-specific claims, they would not have to be compensated. 


\section{Environmental Efficiency}

Three main factors need to be considered in making such interventions environmentally efficient: additionality, leakage, and permanence (Wunder 2007). If the Setulang community is already committed to conserving its forest, would a CCC have any additional effect? Could a CCC have, perversely, a "subtractional" effect, with external payments weakening internal motivations to safeguard the forest (Sengupta et al. 2003)? This is ultimately an empirical question that cannot be resolved beforehand. Nevertheless, given some division of interest within Setulang and incremental protection and opportunity costs (see above), the CCC might provide a tangible, positive economic incentive. Although most people currently do not favor selling their logging rights, if they were to change their minds - a danger indicated by the minority pro-timber voices occasionally heard within the community-this would probably only be known externally once it was too late, and the tipping point had already been passed. This favors being proactive.

Leakage could happen if logging and associated pressures on biodiversity are moved elsewhere. Complete leakage only occurs, however, if logging is wholly demand driven, which it is not. Even a small decrease in the area available for logging reduces its scale. If the Setulang forest has some special biodiversity values, as we suggest, then even partial displacement produces a further net positive outcome. Moreover, if this initiative was successful, other communities might follow suit. Should a local market for conservation services emerge, it could reduce logging more widely.

The permanence of a CCC depends on the duration of the payments and their continued success in protecting biodiversity against both internal and external threats. Obviously, conservation preferences in the village may change, local institutions could fail, funding may cease, or external actors (district government, neighboring villages) might intervene to impose a different outcome. Within current constraints, the proposed CCC design, with equalsized recurrent payments, and some consultation and participation of external actors, seems the most sustainable option.

\section{DISCUSSION}

Why did the CCC initiative fail? On the community side, there was certainly widespread enthusiasm. But, despite initial interest and prolonged negotiations, none of the three prospective donors were convinced enough to support it. Two of the three were eager to finance other activities in Setulang in line with a more conventional Integrated Conservation and Development Project (ICDP). Two common obstacles shaped the outcome.

First, none of the donors had a time horizon to make continuous payments over more than 3 years, yet the funds they offered were insufficient to create a trust fund that would have allowed payments to be stretched over a longer period. Simply financing 3year pilot payments in the hope it could be extended later appeared unsustainable to them. They also implied that paying year after year without changing the rules or logic of the system was unsatisfactory. They preferred a solution that would somehow fix the problem, as they saw it, within their restricted project timeframe. But payments for environmental services (PES) make most sense exactly in those cases where short-term solutions are unlikely to work and the recognition of lasting trade-offs is necessary, as in Setulang.

Second, all the potential donors felt uncomfortable ultimately with the notion of contingent payments. They reasoned that their image of being benevolent benefactors would suffer if they withdrew funding in the case of non-compliance. Moreover, they feared being accused of seeming to be overbearing in their dealings with a poor Indonesian village. Even the international conservation organization, striving to gain a pro-poor image, was concerned about the possibility of having to go against local people's interests.

The donors also raised two important legitimate concerns: uncertain land tenure and the nature of the conservation problem. One donor in particular was apprehensive about the potential for a CCC to exacerbate inter-village conflicts over land. Whereas we agreed that this was an issue, it did not seem to be an absolute impediment. If it was, then a CCC or other area-based PES scheme would be unworkable in any forest-dwelling community in Indonesia (and beyond), because uncertain land tenure is the national norm rather than the exception. Competition and conflict are invariably low wherever land is used extensively and intermittently 
for extracting low-value resources. Tensions emerge when more profitable opportunities, such as timber harvesting or ecotourism - suggested by one of the donors - arise. The advantage of an areabased agreement is that the issue of land tenure is brought into the open, whereas a conventional ICDP tends to obscure it behind a screen of project investments and activities. Common solutions include clarifying the boundaries beforehand, buying out the weaker claims, or sharing the benefits. As it is, the boundary disputes between Setulang and its neighbors have now been resolved, leaving the Tane' Olen intact, albeit for reasons other than establishing a CCC (Godwin Limberg and Ramses Iwan, personal communication, 3 September 2007).

The rationale for any local-level conservation intervention is that the local landholder's preferred land use is sub-optimal for external users of the service, causing a lasting externality. Direct PES, including CCC, is most appropriate where such externalities are likely to persist, making continuous compensation desirable. In contrast, an ICDP may be more suitable when discrete interventions exist that help overcome profitability gaps and eliminate the externality (Wunder 2005). The threat to biodiversity posed by logging the forest at Setulang would seem to be addressed more directly and costeffectively through a CCC. The discrete project interventions suggested to us by the donors - setting up a revolving credit fund and an ecotourism project - appear too expensive and likely to fail. Revolving credit funds in the region have been plagued by high administrative costs and low repayment rates (Holloh 2001, Conroy 2003). Moreover, there is no direct link to conservation. The sustainability of the suggested ecotourism project is also questionable, given the remoteness of the area, difficulties in access, and concerns internationally over security in Indonesia. Local tourism is an option, but is hardly likely to produce sufficient revenue to counterbalance the pressures from logging.

In short, although both approaches face similar challenges, an ICDP seems more costly to initiate and implement. Net benefits received by the community are probably less because of higher overheads and start-up costs. Whereas the sustainability of a CCC depends on ongoing payments, this probably applies to ICDPs as well, because of the need to subsidize unprofitable projects or initiate new ones when others fail. An ICDP probably does not provide the same opportunity for learning and extension as does experimenting with the more innovative CCC.

Ultimately, the innovative notion of "buying biodiversity benefits" was not genuinely reconcilable with the donors' agendas - in either temporal or conditional terms. Their approach reflected a desire to support simultaneously both socioeconomic development and biodiversity conservation, treating them as inextricable. Their agenda is commendably altruistic; they expect little more than a positive public image and all-round gratitude. But this fuzziness of objective could compromise both outcomes. Had poverty alleviation been the overriding concern, then Setulang was probably not the appropriate target; other villages in the region are much poorer. Had biodiversity conservation been the priority, then the Setulang CCC ought to have been supported; a local conservation initiative would have been rewarded (and, incidentally, local incomes would have increased). But, by addressing neither of the objectives directly, little progress was made in achieving either of them.

\section{CONCLUSIONS}

Five main lessons emerge from this study. First, to meet the challenge of successfully reconciling conservation and development, we need to test and refine more innovative approaches. Donors and other potential biodiversity buyers should be encouraged to be more adventurous and support such efforts, despite new modalities and the risks involved. That will require longer time horizons and the courage to employ direct, conditional payments. Given the need for accountability, the conservatism of donors is understandable, but breakthroughs will not happen if opportunities to experiment, observe outcomes, and adapt are missed. Conversely, sticking exclusively to an integrated conservationcum-development agenda is likely to produce inefficient interventions in many hands-on situations, where the generalized problem is the lasting nature of the externality; where forests may not be worth enough to local stakeholders to conserve actively without external compensations, and where there are no quick, discrete fixes.

Second, opportunity costs are the key concept for determining payment size and willingness to accept a CCC. In the case of East Kalimantan, these costs will often be high and front-loaded (due to the profitability of cashing in logging rents), rising over 
time (due to higher company offers), and borne by multiple stakeholders along the value-added chain (see next point). Nevertheless, one should look at net opportunity costs, subtracting internal conservation benefits, e.g., from clean water or game. Even so, economics may not give the full answer, because hard-to-monetarize cultural benefits can also play a role.

Third, the vested land-use interests of external stakeholders cannot be ignored. From timber companies to intermediaries, district government to the national economy, all benefit somehow from timber rents. By foregoing these rents, they would bear corresponding conservation opportunity costs. Approaches that focus exclusively on the immediate land users risk failure because they ignore powerful external stakeholders and the ambiguity of land tenure in tropical forest-frontier settings. Overlapping rights and tenure claims need to be clarified (although not necessarily legally formalized) before a conservation concession can be established. Not all stakeholders with net opportunity costs need to be compensated, but their likely claims must be evaluated and, if necessary, negotiated. Neighbors with historical claims to the area perhaps have the strongest case, but the needs of the district government must also be accommodated because of its political leverage on land use. Some strategic reward - not necessarily recurrent cash paymentsmay be required to build a resilient alliance for conservation. The question of whom to compensate in a conservation concession is thus not merely a mechanical exercise in resource economics. It underpins a strategic approach that is sensitive to the political economy of land use.

Fourth, should one establish a CCC when local people have already opted for conservation in their own interest? Where is the additionality in this case? A positive "ex ante" conservation attitude is certainly a huge advantage for any CCC intervention. Where there is a clear threat of reversal, as in Setulang, with anti-conservation push-and-pull factors intensifying, one cannot say exactly when intra-communal decision making, involving conflicting interests, would lead the majority to abandon its position. The tipping point is hard to predict, but the price of failure is irreversible biodiversity loss. Many potential biodiversity protection scenarios have characteristics where small but strategic preventive payments make sense. The CCC payments should be seen as a strategic insurance premium or marginal subsidy designed to raise the threshold of local net conservation benefits.

Finally, a case like Setulang provides important feedback to the global PES debate: a supply-side bias-focusing one-sidedly on identifying potential service-providing communities and their perceived needs - is unlikely to lead to PES deals. Initiatives at a much larger scale than Setulang, such as Brazilian efforts to establish the public PES program Proambiente in the Amazon, have had that bitter experience (Wunder 2007). Even if PES at a certain site or region clearly seems to be a good idea, it is a "sine qua non" to work from the beginning with the potential service buyers in the design and direction of the proposal. Proactively educating buyers and donors to help them realize the potential benefits of PES, and what reforms would be required from their side to implement the approach, may also be necessary.

Responses to this article can be read online at:

http://www.ecologyandsociety.org/voll3/iss1/art12/responses/

\section{Acknowledgments:}

We thank the EU and IFAD for funding that supported this research. We are grateful to Godwin Limberg, Petrus Gunarso, Doug Sheil, and Moira Moeliono for providing information. Thanks also to Joshua Bishop, Petrus Gunarso, Stefano Pagiola, Doug Sheil, and two anonymous reviewers for helpful comments on earlier versions of this paper.

\section{LITERATURE CITED}

Albán, M., and M. Argüello. 2004. Un análisis de los impactos sociales y económicos de los proyectos de fijación de carbono en el Ecuador. El caso de PROFAFOR - FACE. International Institute for Environment and Development, London, UK.

Alcorn, J. B. 2000. An introduction to the linkages between ecological resilience and governance. Pages 1-16 in J. B. Alcorn and A. G. Royo, editors. Indigenous social movements and ecological resilience: lessons from the Dayak of Indonesia. Biodiversity Support Program, Washington, D.C., USA. 
Anau N., R. Iwan, M. van Heist, G. Limberg, M. Sudana, and E. Wollenberg. 2005. Negotiating more than boundaries: conflict power and agreement building in the demarcation of village borders in Malinau. Pages 19-41 in C. J. P. Colfer, editor. The equitable forest: diversity, community and resource management. Resources for the Future and CIFOR, Washington, D.C., USA.

Barr, C. 2001. Banking on sustainability: structural adjustment and forestry reform in post-Suharto Indonesia. CIFOR and WWF Macroeconomics Program Office, Washington, D.C., USA.

Barr, C., I. A. P. Resosudarmo, A. Dermawan, and J. F. McCarthy, editors; with M. Moeliono and B. Setiono. 2006. Decentralization of forest administration in Indonesia: implications for forest sustainability, economic development and community livelihoods. CIFOR, Bogor, Indonesia.

Barr, C., E. Wollenberg, G. Limberg, N. Anau, R. Iwan, I. M. Sudana, M. Moeliono, and T. Djogo. 2001. The impacts of decentralisation on forests and forest-dependent communities in Malinau district, East Kalimantan. Case Studies on Decentralisation and Forests in Indonesia, No.3. CIFOR, Bogor, Indonesia.

Brandon, K., K. H. Redford, and S. E. Sanderson, editors. 1998. Parks in peril: people, politics, and protected areas. Island Press, Washington, D.C., USA.

Brown, D. W. 1999. Addicted to rent: corporate and spatial distribution of forest resources in Indonesia; implications for forest sustainability and government policy. Report No. PFM/EC/99/06, Indonesia UK Tropical Forestry Management Programme, Jakarta, Indonesia. [online] URL: http://www.geoc ities.com/davidbrown id/Atr main.html.

Casson, A., and K. Obidzinski. 2007. From new order to regional autonomy: shifting dynamics of illegal logging in Kalimantan, Indonesia. Pages 4368 in L. Tacconi, editor. Illegal logging. Law enforcement, livelihoods and the timber trade. Earthscan, London, UK.

Claassen, R., A. Cattaneo, and R. Johansson. 2008. Cost-effective design of agri-environmental payment programs: U.S. experience in theory and practice. Ecological Economics: accepted.
Conroy, J. D. 2003. The challenges of microfinancing in Southeast Asia. Pages 97-161 in N. J. Freeman, editor. Financing Southeast Asia's economic development. Institute of Southeast Asia Studies, Singapore. [online] URL: http://fdc.org.au/ Files/Microfinance/Challenges\%20of\%20MF.pdf

de Beer, J. 2003. Establishing community conservation concessions-Malinau, Indonesia. Unpublished Report, World Conservation Union (IUCN), Gland, Switzerland.

Echavarría, M., J. Vogel, M. Albán, and F. Meneses. 2004. The impacts of payments for watershed services in Ecuador. Emerging lessons from Pimampiro and Cuenca. International Institute for Environment and Development, London, UK. [online] URL: http://www.iied.org/pubs/pdfs/9285IIED. pdf.

Engel, S., and C. Palmer. 2006. Who owns the right? The determinants of community benefits from logging in Indonesia. Forest Policy and Economics 8:434-446.

Ferraro, P. J. 2001. Global habitat protection: limitations of development interventions and a role for conservation performance payments. Conservation Biology 15(4):990-1000.

Ferraro, P., and A. Kiss. 2002. Direct payments to conserve biodiversity. Science 298:1718-1719.

Ferraro, P., and R. Simpson. 2002. The costeffectiveness of conservation payments. Land Economics 78(3):339-353.

Ferraro, P., and R. Simpson. 2005. Protecting forests and biodiversity: are investments in ecofriendly production activities the best way to protect endangered ecosystems and enhance rural livelihoods? Forests, Trees and Livelihoods 15:167181.

Fuller, D. O., T. C. Jessup, and A. Salim. 2004. Loss of forest cover in Kalimantan, Indonesia, since the 1997-1998 El Niño. Conservation Biology 18:249-254.

Forest Watch Indonesia/Global Forest Watch. 2002. The state of the forest: Indonesia. Forest Watch Indonesia, Bogor, Indonesia, and Global Forest Watch, Washington, D.C., USA. 
Grieg-Gran, M., I. T. Porras, and S. Wunder. 2005. How can market mechanisms for forest environmental services help the poor? Preliminary lessons from Latin America. World Development 33:1511-1527.

Gunarso, P., W. Widyati, Zakaria, and K. D. Santosa. 2006. Pengembangan pengelolaan hutan oleh masyarakat di desa Setarap dan Setulang, Kecamatan Malinau Selatan dan desa Sentaban Kecamatan Malinau Barat Kabupaten Malinau (with English summary). Final Report IUCN-MRF CIFOR Small Grants Project, CIFOR, Bogor, Indonesia.

Hardner, J., and R. Rice. 2002. Rethinking green consumerism. Scientific American 286(5):89-95.

Hassan, R., R. Scholes, and N. Ash, editors. 2005. Ecosystems and human well-being: current state and trends, Volume 1. Island Press, Washington, D. C., USA.

Holloh, D. 2001. Review of the KDP microcredit approach. Report prepared for the World Bank, Jakarta Office. World Bank, Washington D.C., USA. [online] URL: http://lnweb18.worldbank.org/ ESSD/sdvext.nsf/09ByDocName/ReviewoftheKDP MicrocreditApproach/\$FILE/Holloh+(2001)+KDP1+ Microcredit+Review.pdf.

Holmes, D. 2002. Where have all the forests gone? Environment and Social Development East Asia and Pacific Region Discussion Paper. World Bank, Washington, D.C. [online] URL: http://www-wds.w orldbank.org/external/default/WDSContentServer/WDSP/ IB/2002/08/09/000094946 02072604202380/Rendered/ PDF/multi0page.pdf

Hooper, D. U., F. S. Chapin, III, J. J. Ewel, A. Hector, P. Inchausti, S. Lavorel, J. H. Lawton, D. M. Lodge, M. Loreau, S. Naeem, B. Schmid, H. Setälä, A. J. Symstad, J. Vandermeer, and D. A. Wardle. 2005. Effects of biodiversity on ecosystem functioning: a consensus of current knowledge. Ecological Monographs 75:3-35.

Iwan, R. 2003. Setulang village protects its river! Policy Matters 12:152-153.

Iwan, R. 2004. Mobilizing community conservation: a community initiative to protect its forest against logging in Indonesia. Paper presented at the Xth
Meeting of the International Association for the Study of Common Property, 9-13 August 2004, Oaxaca, Mexico. [online] URL: http://dlc.dlib.india na.edu/archive/00001415/00/Iwan Mobilizing 040 524 Paper176d.pdf.

Iwan, R. 2006. Tane' Olen: a piece in the village landscape. Land use planning in Setulang Village, East Kalimantan. Paper presented at the session "Survival of the Commons: Mounting Challenges and New Realities", $11^{\text {th }}$ Conference of the International Association for the Study of Common Property, Bali, Indonesia, 19-23 June 2006. [online] URL: http://dlc.dlib.indiana.edu/archive/00001924/00/ Iwan Ramses.pdf.

Karsenty, A. 2004. Des rentes contre le développement? Les nouveaux instruments d'acquisition mondiale de la biodiversité et l'utilisation des terres dans les pays tropicaux. Mondes en développement 127:1-9.

Kiss, A. 2004. Is community-based tourism a good use of biodiversity conservation funds? Trends in Ecology and Evolution 19:232-237

Kramer, R. A., C. P. van Schaik, and J. Johnson, editors. 1997. The last stand: protected areas and the defense of tropical biodiversity. Oxford University Press, New York, New York, USA.

Li, T. M. 2001. Masyarakat adat, difference, and the limits of recognition in Indonesia's forest zone. Modern Asian Studies 35:645-676.

Limberg, G., R. Iwan, M. Moeliono, M. Sudana, and E. Wollenberg. 2007. Community-based forestry and management planning. Pages 99-118 in P. Gunarso, T. Setywati, T. Sutherland, and C. Shackleton, editors. Managing forest resources in a decentralized environment: lessons learnt from the Malinau Research Forest, East Kalimantan Indonesia. Center for International Forestry Research, Bogor, Indonesia.

Meijaard, E., D. Sheil, R. Nasi, D. Augeri, B. Rosenbaum, D. Iskandar, T. Setyawati, M. Lammertink, I. Rachmatika, A. Wong, T. Soehartono, S. Stanley, and T. O'Brien. 2005. Life after logging: reconciling wildlife conservation and production forestry in Indonesia Borneo. Center for International Forestry Research, Bogor, Indonesia. 
Niesten, E., and R. Rice. 2004. Sustainable forest management and conservation incentive agreements. International Forestry Review 6:56-60.

Obidzinski, K. 2005. Illegal logging and the fate of Indonesia's forests in times of regional autonomy. Pages 429-449 in Tanah masih di langit: penyelesaian masalah penguasaan dan kekayaan alam di Indonesia yang tak kunjung tuntas di era reformasi. Yayasan Kemala, Jakarta, Indonesia.

Pagiola, S. 2008. Payments for environmental services in Costa Rica, Ecological Economics (accepted).

Pagiola, S., P. Agostini, J. Gobbi, C. de Haan, M. Ibrahim, E. Murgueitio, E. Ramírez, M. Rosales, and J. P. Ruíz. 2004. Paying for biodiversity conservation services in agricultural landscapes. World Bank, Washington, D.C., USA.

Pagiola, S., E. Ramírez, J. Gobbi, C. de Haan, M. Ibrahim, E. Murgueitio, and J. P. Ruíz. 2007. Paying for the environmental services of silvopastoral practices in Nicaragua. Ecological Economics 64:374-385.

Palmer, C. 2007. The role of leadership in the collective enforcement of community property rights in Indonesia. Society and Natural Resources 20:397-413.

Perrot-Maître, D. 2006. The Vittel payments for ecosystem services: a "perfectÝ PES case? International Institute for Environment and Development, London, UK. [online] URL: http://w ww.iied.org/NR/forestry/documents/Vittelpayment sforecosystemservices.pdf.

Romero, C., and G. I. Andrade. 2004. International conservation organizations and the fate of local tropical forest conservation initiatives. Conservation Biology 18:578-580.

Sengupta, S., K. Mitra, S. Saigal, R. Gupta, S. Tiwari, and N. Peters. 2003. Developing markets for watershed protection services and improved livelihoods in India. Winrock International India, New Delhi and International Institute for Environment and Development, London, U.K. (unpublished draft) [online] URL: http://www.iied. org/NR/forestry/documents/Watershed Markets In dia Scoping Report.pdf.
Sheil, D. 2002. Biodiversity research in Malinau. Pages 57-107 in CIFOR, ITTO project PD 12/97 Rev.1 (F). Forest, science and sustainability: the Bulungan model forest. Technical Report Phase 1, 1997-2001. Center for International Forestry Research and International Timber Trade Organization, Bogor, Indonesia.

Sidiyasa, K., Zakaria, and R. Iwan. 2006. The forests of Setulang and Sengayan in Malinau, East Kalimantan: their potential and the identification of steps for their protection and sustainable management. Center for International Forestry Research, Bogor, Indonesia.

Simpson, R., and R. A. Sedjo. 1996. Paying for the conservation of endangered ecosystems: a comparison of direct and indirect approaches. Environment and Development Economics 1:241257.

Smith, J., K. Obidzinski, S. Subarudi, and I. Suramenggala. 2007. Illegal logging, collusive corruption and fragmented governments in Kalimantan, Indonesia. Pages 91-109 in L. Tacconi, editor. Illegal logging. Law enforcement, livelihoods and the timber trade. Earthscan, London, UK.

Turpie, J. K., C. Marais, and J. N. Blignaut. 2008. The Working for Water Programme: evolution of a payments for ecosystem services mechanism that addresses both poverty and ecosystem service delivery in South Africa. Ecological Economics (accepted).

Wollenberg, E., R. Iwan, G. Limberg, M. Moeliono, S. Rhee, and M. Sudana. 2007. Facilitating cooperation during times of chaos: spontaneous orders and muddling through in Malinau District, Indonesia. Pages 57-58 in P. Gunarso, T. Setyawati, T. Sunderland, and C. Shackleton, editors. Managing forest resources in a decentralized environment: lessons learned from the Malinau Research Forest, East Kalimantan Indonesia. Technical Report, ITTO PD 39/00 Rev. 3(F). Center for International Forestry Research, Bogor, Indonesia.

Wollenberg, E., M. Moeliono, G. Limberg, R. Iwan, S. Rhee, M. Sudana. 2006. Between state and society: local governance of forests in Malinau, Indonesia. Forest Policy and Economics 8:421-433. 
Wunder, S. 2005. Payments for environmental services: some nuts and bolts. CIFOR Occasional Paper No. 42. Center for International Forestry Research, Jakarta, Indonesia. [online] URL: http:// www.cifor.cgiar.org/publications/pdf files/OccPapers/ OP-42.pdf.

Wunder, S. 2007. The efficiency of payments for environmental services in tropical conservation. Conservation Biology 21:48-58.

Wunder, S., and M. Albán. 2008. Decentralized payments for environmental services: comparing the cases of Pimampiro and PROFAFOR in Ecuador. Ecological Economics (accepted). 